\title{
Effect of season on production and quality of milk of crossbred dairy cows at Sylhet district government dairy farm in Bangladesh
}

\author{
Zaman MA, A Ara and MN Haque
}

Faculty of Veterinary and Animal Science, Sylhet Agricultural University, Sylhet-3100, Bangladesh

\begin{abstract}
The present study was conducted to investigate the seasonal effect on milk production and milk qualities of crossbred dairy cows at DGDF, Sylhet. For these purposes, the data of milk production and milk samples were collected from bulk milk tank at District Govt. Dairy Farm, Sylhet and their qualities were measured by physico-chemical and microbiological tests. The season has a significant effect $(p<0.05)$ on the milk yield and milk quality. The total milk production was highest during the rainy season 3354.00 $\mathrm{kg}$ followed by summer $3116.70 \mathrm{~kg}$ while the lowest milk production was obtained in winter $2925.50 \mathrm{~kg}$. The chemical composition of milk was the lowest in summer $4.27 \%$ fat, $3.20 \%$ protein, $4.46 \%$ lactose and $8.55 \%$ SNF and in rainy $3.96 \%$ fat, $3.24 \%$ protein, $4.49 \%$ lactose and $8.53 \%$ SNF respectively and the highest in winter $5.30 \%$ fat, $3.18 \%$ protein, $4.46 \%$ lactose and $8.59 \%$ SNF. The season had a significant influence on the density and freezing point of the milk $(p<0.05)$. The temperature of the milk varied widely from one season to another season. The temperature was maximum in rainy season $28.77^{\circ} \mathrm{C}$ while the minimum was $25.80{ }^{\circ} \mathrm{C}$ in the winter season. The salt percentage of the milk varied within a small range from one season to another season. During the winter season the average SPC bacteria count was lower compared with the other season, $38.02 \times 10^{5} \mathrm{cfu} / \mathrm{ml}$. The highest value was obtained in rainy season $40.50 \times 10^{5} \mathrm{cfu} / \mathrm{ml}$. Coliform bacteria count was on average $4.5 \times 10^{5} \mathrm{cfu} / \mathrm{ml}$ in winter, $4.91 \times 10^{5} \mathrm{cfu} / \mathrm{ml}$ in summer and $5.46 \times 10^{5} \mathrm{cfu} / \mathrm{ml}$ in rainy season. There was no significant difference compared to the value found during the other season. From this study it was found that season had a significant effect on the milk quantity and quality, except for protein, lactose, SNF, SPC and coliforms count.
\end{abstract}

Key words: milk, season, physio chemical properties, coliform

Bangladesh Animal Husbandry Association. All rights reserved.

Bang. J. Anim. Sci. 2016. 45 (3): 52-57

\section{Introduction}

Bangladesh is a country of small and mixed farms where crop, livestock, fisheries and homestead forestry are the major components of the farming systems. Livestock are well integrated into the mixed farming system in Bangladesh, where $25 \%$ of the population are directly involved in livestock production and another $60 \%$ are indirectly involved (Bangladesh Economic Review, 2001). The total cattle population in Bangladesh is estimated as 24 million (DLS, 2008), out of which 6 million are dairy cattle (DLS, 2008) consisting of local (31.45\%) and crossbreds (68.55\%) reported by Huque et al., (2002). Milk has long been recognized as an valuable food all over the world, also it is a nutrient food and contributes a high proportion of the nutrients, such as micronutrients, include calcium, phosphorus, vitamins like $B$ and $D$, high quality protein such as casein protein, also fatty acid composition of milk fat has relation to its potential health benefit and impact on the human health (Frelich et al., 2012). The composition of normal cow's milk varies to a great extent. Milk fat is very important for health and it provides the concentrated source of energy and each gram of fat furnishes 9 calories energy which is 2.25 times more than protein and carbohydrate. Milk protein has a high nutritive value due to the content of all essential amino acids and high digestibility. Milk protein level decreased in the hot month was due to the decrease in the casein that it means reduction in $\beta$-casein and a-casein (Bernabucci et al., 2002). Lactose the only milk sugar is an excellent food for babies. Lactose has favourable influence on the utilization of calcium through formation of calcium lactate in the intestine. Milk is an

\section{*Corresponding author: ashik.sau02@gmail.com}




\section{Effect of season on milk production and quality}

excellent source of calcium and phosphorus, which are important in the formation of bone and teeth.

Understanding the variability in milk yield, milk composition, physical and hygienic parameters of milk is important when making management decisions and in milk-recording programs (Cziszter, 2012). Broadly, there are 3 options for altering the composition and/or functional properties of milk, cow nutrition and management, cow genetics, and dairy manufacturing technologies (Walker et al., 2004). The chemical composition of milk varies greatly as a consequence of numerous factors such as species, breed of animal, climate, season, lactation etc. Feeding system and Seasonal variation have effect in composition of milk especially in fatty acid (Frelich et al., 2012). Between the environmental factors the feeding of cows and season of the year has a considerable influence on milk components and properties (Cziszter, 2012). The different season of the year is often related to different food regimes for cows. Food intake, kind and quality of fodder are connected to the food regime. This regime has also effects on the milk composition (Rajeevie et al., 2003).

Environmental conditions directly influence the milk production quantitatively and qualitatively (Cziszter et al., 2012). It was observed from various study that in seasons with high temperatures (summer and early autumn) milk production increases and decreases in the low temperature (Cziszter, 2012). The freezing point of milk depends upon the concentration of watersoluble components and some others. The current official freezing point limit $\left(-0.505^{\circ} \mathrm{C}\right)$ was designed for whole-herd, bulk-tank samples or processed milk samples. Diet and how and when the diet is fed relative to collecting the milk sample, also may affect freezing point from individual cows (Janštová et al., 2007).

The repeated experiment on seasonal effect on milk production and quality would be a valuable addition in dairy science. Considering the above facts the objectives of this study were: to assess the milk production in different season of crossbred dairy cows at District Government Dairy Farm, Sylhet and to evaluate the physico- chemical properties and microbial quality of milk in different season of crossbred dairy cows.

\section{Materials and Methods}

\section{Experimental site and period}

The present study was conducted at District Government Dairy Farm, Sylhet where the dairy cows were mainly crossbred type (HF $\times$ Local, HF $\times$ Sahiwal) and Dairy Technology Laboratory under the Department of Dairy Science, Sylhet Agricultural University, Sylhet during the period from December 2014 to August 2015. The study period was divided into three seasons; winter (December to February), summer (March to May) and Rainy (June to August).

\section{Management practices}

In District Government Dairy Farm, Sylhet, the housing system was tail to tail housing system. Daily 2-2.5 kg concentrate (wheat bran 50\%, maize $10 \%$, rice polish $12 \%$, pulses $15 \%$, oil cake $11 \%$, salt $1 \%$ and minerals $1 \%$ ) and $10-12$ $\mathrm{kg}$ roughages ( $80 \%$ green grass and $20 \%$ straw) were provided to the cows for feeding in summer season. In rainy season $2-2.5 \mathrm{~kg}$ concentrate/day (wheat bran $50 \%$, maize $10 \%$, rice polish $12 \%$, pulses $15 \%$, oil cake $11 \%$, salt $1 \%$ and minerals $1 \%$ ) and $11-13 \mathrm{~kg}$ roughages/day ( $80 \%$ green grass and $20 \%$ straw) were supplied to the cows. On the other hand, in winter season daily 1.5-2.5 $\mathrm{kg}$ concentrate and $8-10 \mathrm{~kg}$ roughages (40\% green grass and $60 \%$ straw) were supplied to the animals. The average environmental temperature in summer, rainy and winter season were $32^{\circ} \mathrm{C}$, $31^{\circ} \mathrm{C}$ and $13^{\circ} \mathrm{C}$ respectively.

\section{Collection of samples}

The milk samples were collected from the bulk milk tank at morning and the number of cows in milked was recorded in the farm record book daily. A total of 119 samples in which 40 samples in winter, 38 samples in summer and 41 samples in rainy season were collected from the milk bulk tank. Samples were collected in sample bottles and immediately carried out in the laboratory under the Department of Dairy Science, Sylhet Agricultural University, Sylhet for chemical and microbial analysis. Production data was collected from daily record book of farm. Total number of milch cows in winter, summer 
and rainy season were 23, 22 and 25 respectively.

\section{Physico-chemical analysis}

Chemical compositions (fat, protein, lactose, SNF, salt) as well as the freezing point, density of collected milk samples were carried out by using the Milk Analyzer (Lactoscan, Bulgaria).

\section{Microbiological examinations}

The experimental procedures followed for the determination of the number of total viable bacteria in a sample and the detection and enumeration of coliforms bacteria were as per recommendation American Public Health Association (APHA., 1998).

\section{Statistical analysis}

A Completely Randomized Design (CRD) was followed for statistical analysis. The significance of fixed effects were tested conducting leastsquares analyses of variance using the general linear model (GLM) procedure of the Statistical Analysis System (SAS, 1998) according to the following linear model:

$Y_{i m}=\mu+S_{i}+E_{i m}$,

where $Y_{i m}$ is the dependent variable (individual animal record for the trait), $\mu$ is the overall mean, $S_{i}$ is the fixed effect of $i^{\text {th }}$ season and $E_{i m}$ is the residual error. The year was divided into three seasons; winter (December to February), summer (March to May) and Rainy (June to August). Duncan's multiple range tests was used to detect significant differences between means.

\section{Results and Discussion}

The season had a significant effect $(p<0.05)$ on the milk yield, milk quality and less effect on the physical properties of the milk. The effects of season on the milk production are presented in Table 1. The highest milk production was obtained during the rainy season $3354.00 \mathrm{~kg}$, followed by summer $3116.70 \mathrm{~kg}$ while the lowest average milk production was obtained in winter $2925.50 \mathrm{~kg}$. This result was similar to the findings of Neciu et al., (2012) and Cziszter et al., (2012). Cziszter et al., (2012) found highest milk yield was $3727.6 \mathrm{~kg} /$ day from 251 milch cows in summer and lowest was $3016.6 \mathrm{~kg} /$ day from 254 cows during winter. This seasonal variation of the milk yield is due to the milk secretion stimulation by the green fodder, which is fed to cows during the summer and rainy season of the year and the number of cows in milked. Differences between seasons for average milk production were statistically significant $(p<0.05)$, except for the difference between summer and rainy season milk production were not statistically significant $(p>0.05)$.

Seasonal distribution of the chemical composition of the raw milk from the bulk tank is presented in Table 2. As opposite to the milk yield, the chemical composition of bulk tank milk was the lowest in summer $4.27 \%$ fat, $3.20 \%$ protein, $4.46 \%$ lactose and $8.55 \%$ SNF and rainy $3.96 \%$ fat, $3.24 \%$ protein, $4.49 \%$ lactose and $8.53 \%$ SNF respectively and the highest was in winter $5.30 \%$ fat. When milk production decreases, fat $\%$ increases. In winter milk yield was low so that fat $\%$ was higher, it also depends on feed item.

Table 1. Milk production of herd in different season

\begin{tabular}{lccc}
\hline \multicolumn{1}{c}{ Season } & $\begin{array}{c}\text { No. of cows } \\
\text { milked }\end{array}$ & Production (Kg/month) & Level of Significance \\
\hline Winter (December-February) & 23 & $2925.50^{\mathrm{b}} \pm 20.068$ & $*$ \\
Summer (March-May) & 22 & $3116.70^{\mathrm{a}} \pm 23.083$ & $*$ \\
Rainy(June-August) & 25 & $3354.00^{\mathrm{a}} \pm 22.587$ & $*$ \\
\hline
\end{tabular}

Means with different superscripts within column and parameters differed significantly $(p<0.05), * ; p<0.05$ 
Table 2. Physio-chemical parameters of milk samples collected from various season at Sylhet District Government Dairy Farm

\begin{tabular}{lrrrr}
\hline \multicolumn{1}{c}{ Parameters } & \multicolumn{3}{c}{ Season } & Level of Significance \\
\cline { 2 - 4 } & Winter $(\mathbf{n = 4 0})$ & Summer $(\mathbf{n = 3 8})$ & Rainy $(\mathbf{n = 4 1})$ & $*$ \\
\hline Fat (\%) & $5.30^{\mathrm{a}} \pm 0.04$ & $4.27^{\mathrm{b}} \pm 0.06$ & $3.96^{\mathrm{b}} \pm 0.05$ & $\mathrm{NS}$ \\
Protein (\%) & $3.18 \pm 0.03$ & $3.20 \pm 0.02$ & $3.24 \pm 0.05$ & $\mathrm{NS}$ \\
Lactose (\%) & $4.46 \pm 0.06$ & $4.46 \pm 0.03$ & $4.49 \pm 0.05$ & $\mathrm{NS}$ \\
SNF (\%) & $8.59 \pm 0.04$ & $8.55 \pm 0.01$ & $8.53 \pm 0.03$ & $*$ \\
Density (\%) & $27.73^{\mathrm{b}} \pm 0.03$ & $28.89^{\mathrm{a}} \pm 0.10$ & $28.73^{\mathrm{a}} \pm 0.08$ & $*$ \\
FP $\left({ }^{\circ} \mathrm{C}\right)$ & $-0.51^{\mathrm{b}} \pm 0.009$ & $-0.52^{\mathrm{ab}} \pm 0.004$ & $-0.54^{\mathrm{a}} \pm 0.006$ & $*$ \\
Temperature $\left({ }^{\circ} \mathrm{C}\right)$ & $25.80^{\mathrm{b}} \pm 0.05$ & $28.27^{\mathrm{a}} \pm 0.03$ & $28.77^{\mathrm{a}} \pm 0.04$ & $*$ \\
Salt $(\%)$ & $0.65^{\mathrm{b}} \pm 0.004$ & $0.66^{\mathrm{a}} \pm 0.001$ & $0.66^{\mathrm{a}} \pm 0.003$ & $*$ \\
\hline
\end{tabular}

Means with different superscripts within each column and parameters differed significantly $(p<0.05)$, NS $=$ Non significant, $*=p<0.05$

The highest milk fat percentage was found in winter $5.30 \%$. The minimum value for fat percentage was observed in rainy $3.96 \%$. Protein percentage ranged from a minimum value of $3.18 \%$ observed in winter and the maximum value $3.24 \%$ was observed in rainy season. Similar findings were observed by Leila et al., (2014) and this happened due to increase milk yield in summer and rainy season than winter. The minimum value for lactose percentage was $4.46 \%$ in winter and summer while the maximum value of $4.49 \%$ was obtained in rainy Season has greatly affected the chemical composition of the bulk tank milk, the differences between seasons for fat percentage being statistically significant $(p<0.05)$. This results are consistent with those presented by other scientists (Cziszter et al., 2007; Sala et al., 2007), showing that the milk composition was lower in summer than in winter because of milk production was higher in summer than winter. Physical properties of the raw bulk tank milk from season to season are presented in Table 2 . The freezing point of the milk varied within a small range from one season to another season. The highest average for freezing point was observed during rainy $-0.54^{\circ} \mathrm{C}$, while the lowest value was $-0.51^{\circ} \mathrm{C}$ obtained during the winter. Generally, the season had a significant influence on the freezing point of the milk $(p<0.05)$ due to variation in environmental temperature. Density of the bulk tank milk was ranging within the normal limits from season to season (Table 2). The highest density of milk was recorded in summer $28.89 \%$, while the lowest was observed in winter $27.73 \%$. The season had a significant effect on the density of the milk $(p<0.05)$. This result of freezing point and density was similar to the findings of Cziszter et al., (2012). The temperature of the milk varied widely from one season to another season. The highest value for temperature was observed during rainy $28.77^{\circ} \mathrm{C}$, while the lowest value was $25.80^{\circ} \mathrm{C}$ obtained during the winter season. This variation occurred due to variation in environmental temperature that was higher in summer and rainy than winter season. The influence of season on the temperature of the milk was significant $(p<0.05)$.

The salt of the milk varied within a small range from one season to another season. The highest average value for salt was observed during summer and rainy $0.66 \%$ while the lowest value was $0.65 \%$ obtained during the winter. The season had a significant influence on the salt percentage of the milk $(p<0.05)$. 
Table 3. Microbial quality of milk samples collected from various season at Sylhet District Government Dairy Farm

\begin{tabular}{lcccc}
\hline Season & No. & SPC $(\mathbf{c f u} / \mathbf{m l})$ & Coliform $\mathbf{( c f u} / \mathbf{m l})$ & Level of significance \\
\hline Winter & 40 & $(38.02 \pm 0.004) \times 10^{5}$ & $(4.50 \pm 0.006) \times 10^{5}$ & Non significant \\
Summer & 38 & $(38.83 \pm 0.005) \times 10^{5}$ & $(4.91 \pm 0.008) \times 10^{5}$ & Non significant \\
Rainy & 41 & $(40.50 \pm 0.003) \times 10^{5}$ & $(5.46 \pm 0.006) \times 10^{5}$ & Non significant \\
\hline
\end{tabular}

Average for total SPC count in bulk tank milk was within the accepted limits in all season (Table 3). During the winter season the average SPC bacteria count was lower compared with the other season $38.02 \times 10^{5} \mathrm{cfu} / \mathrm{ml}$. The highest value was obtained in rainy season $40.5 \times 10^{5} \mathrm{cfu} / \mathrm{ml}$. In this section the tests result shows the bacterial count of raw milk, but people consume that milkafter boiling. So, the chance of gastrointestinal infection is less. Coliform bacteria count was on average $4.5 \times 10^{5} \mathrm{cfu} / \mathrm{ml}$ in winter, $4.91 \times 10^{5} \mathrm{cfu} / \mathrm{ml}$ in summer, and $5.46 \times 10^{5} \mathrm{cfu} / \mathrm{ml}$ in rainy season. There was no significant differences compared to the value found during the other season. This present observation for microbial quality of milk in different seasons are comparable with the previous findings by Cziszter et al., (2012).

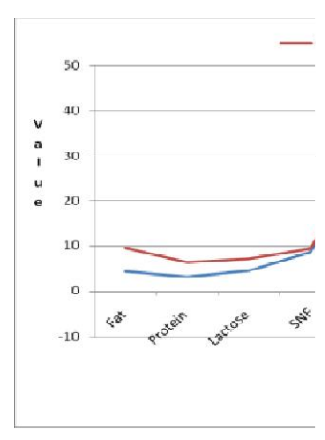

Figure 1. LSM and Co-efficient of variation (CoV) of milk parameters in different season

The LSM and CoV of parameters for three seasons such as production, fat, protein, lactose, SNF, density, FP, temperature, salt , SPC and coliforms were $3082.33 \mathrm{~kg}$ and $3.37 \mathrm{~kg}, 4.32 \%$ and $5.04 \%, 3.20 \%$ and $3.19 \%, 4.47 \%$ and $2.58 \%, 8.53 \%$ and $0.73 \%, 28.72 \%$ and 1.43 $\mathrm{kg} / \mathrm{m}^{3},-0.521^{\circ} \mathrm{c}$ and $-2.66^{\circ} \mathrm{c}, 28.10^{\circ} \mathrm{c}$ and $2.69^{\circ} \mathrm{c}$, $0.66 \%$ and $0.93 \%, \quad 39.16 \times 10^{5} \mathrm{cfu} / \mathrm{ml}$ and $6.95 \times 10^{5} \mathrm{cfu} / \mathrm{ml}$, $\quad 4.88 \times 10^{5} \mathrm{cfu} / \mathrm{ml}$ and $16.20 \times 10^{5} \mathrm{cfu} / \mathrm{ml}$ respectively (Figure 1 .).

\section{Conclusion}

Season had a significant effect on the bulk tank raw milk quantity and quality, except for protein, lactose, SNF, SPC and Coliform count. The highest milk production with the lowest concentration being obtained during rainy and summer season, on the other hand the lowest milk production with the highest fat percentage was obtained during winter season. The physical properties of the milk sample were less affected by the season. The lowest freezing point, density and temperature were found in winter rather than rainy and summer. On the basis of this study, it can be suggested that if we identify the factors that are influence the milk production overall the year and it can be helpful to the dairy owner for marketing milk commercially.

\section{References}

American Public Health Association, Inc. (1998). Chapter 7.

Bangladesh Economic Review (2001).

Bernabucci N, B Lacetera, A Ronchi snd Nardone (2002). Anim. Res. 51:25-33.

Cziszter LT, S Acatincăi, FC Neciu, R Neamt, DE Ilie, L Costin and I Tripon (2012). The Influence of Season on the Cow Milk Quantity, Quality and Hygiene. Scientific Papers: Animal Science and Biotechnologies. 45: (2).

DLS (Department of Livestock Services) (2008). Special Bulletin on Economic review of livestock and poultry exhibition. Directorate of livestock services, Ministry of Livestock and Fisheries, Dhaka, Bangladesh.

Frelich M, O Šlachta, J Hanuš, E Špička, A Samková, P Węglarz and Zapletal (2012). Animal Science Papers and Reports. 30(3): 219-229.

Huque KS, MM Rahman and MR Islam (2002). Farming characteristics of cooperative dairy production systems in Bangladesh. Bangladesh Journal of Livestock Research, 9 (I\&2): t7-29. 
Janštová $B$, M Dračková, $\mathrm{P}$ Navrátilová, L Hadra and L Vorlová (2007). Freezing point of raw and heat-treated goat milk. Czech Journal of Animal Science, 52: 394-398.

Leila N, Y Morvarid, Z Elham, G Mohammad and M Mehran (2014). The effect of different seasons on the milk quality. European Journal of Experimental Biology, 4(1): 550552.

Neciu FC, LT Cziszter, RI Neamt, DE Ilie and L Costin (2012). Influence of season on raw milk yield and quality in a dairy farm. Lucrări Ştiinţifice Seria Zootehnie, vol. 58.115-121.
Rajeevie M, K Potoenik and J Levestek (2003). Agriculture Conspectus Scientificus. 68(3): 221-226.

Sala C, G Milovan, A Morar and L Cziszter (2007). Raw milk quality in the farms from the west of Romania, Romanian Review of Veterinary Medicine, 17(2):142-146.

SAS (1998): SAS Users Guide. SAS Institute Inc., Cary, North Carolina, USA.

Walker GP, FR Dunshea and PT Doyle (2004). Effects of nutrition and management on the production and composition of milk fat and protein: a review, Australian Journal of Agricultural Research, 10: 1009-1028. 